\title{
Pengaruh Profitabilitas, Dividend Payout Ratio dan Inflasi Terhadap Harga Saham
}

\author{
(Effect of Profitability, Dividend Payout Ratio and Inflation on Stock \\ Prices)
}

\author{
Herman Setiawan, Victoria, Karen Victoria, Erika, Holfian Daulat Tambun Saribu* \\ Program Studi Manajemen Fakultas Ekonomi Universitas Prima Indonesia \\ Medan, Sumatera Utara, Indonesia \\ Email: holfiandts@yahoo.co.id
}

\begin{abstract}
Abstrak
Kehadiran pasar modal di Indonesia ditandai dengan banyaknya investor yang melakukan pembelian saham terhadap Entitas yang terdaftar di pasar modal. Tujuan penelitian ini ialah menguji dan menganalisis pengaruh profitabilitas, dividend payout ratio dan inflasi terhadap harga saham pada Entitas Barang Konsumsi yang terdaftar di Bursa Efek Indonesia Tahun 2014-2018. Jenis penelitian ini adalah kuantitatif. Populasi penelitian ini adalah 41 perusahaan barang konsumsi yang terdaftar di Bursa Efek Indonesia periode 2014-2018, sampel penelitian ini adalah 17 perusahan x 5 tahun = 85 sampel. Metode analisis data penelitian ini adalah dengan menggunakan regresi linear berganda dengan SPSS. Hasil penelitian ini adalah Profitabilitas berpengaruh dan signifikan terhadap harga saham sedangkan Dividend Payout Ratio dan inflasi tidak berpengaruh terhadap Harga Saham, dan secara simultan Profitabilitas, Dividen Payout Ratio dan inflasi berpengaruh dan signifikan terhadap Harga Saham Pada Entitas Barang Konsumsi yang terdaftar di Bursa Efek Indonesia Tahun 2014-2018.
\end{abstract}

Kata Kunci: Profitabilitas, Dividend Payout Ratio, Inflasi, dan Harga Saham

\begin{abstract}
The presence of the capital market in Indonesia is marked by the number of investors who purchase shares of entities that are registered in the capital market. The purpose of this research is to examine and analyze the effect of profitability, dividend payout ratio and inflation on share prices in consumer goods entities listed on the Indonesia Stock Exchange in 2014-2018. This type of research is quantitative. The population of this study is 41 consumer goods companies listed on the Indonesia Stock Exchange for the period 2014-2018, the sample of this study is 17 companies $x 5$ years $=85$ samples. The data analysis method of this research is to use multiple linear regression with SPSS. The results of this study are Profitability has a significant and significant effect on stock prices, while Dividend Payout Ratio and inflation have no effect on Stock Prices, and simultaneously Profitability, Dividend Payout Ratio and inflation have a significant and significant effecton Share Prices in Consumer Goods Entities listed on the Indonesia Stock Exchange. 2014-2018.
\end{abstract}

Keywords: Profitability, Dividend Payout Ratio, Inflation, and Stock Prices

\section{Pendahuluan}

Pasar modal Indonesia dijadikan sebagai wahana untuk memperjualbelikan saham Entitas. Entitas berada di pasar modal salah satunya termasuk Entitas barang konsumsi. Entitas ini memperjualbelikan saham ataupun obligasi dengan tujuan mendapatkan investasi jangka pendek dari investor sedangkan para investor mengharapkan perolehan pendapatan dari sahamnya ataupun obligasi dibelinya. Saham yang diperjualbelikan memiliki harga tertentu. Harga sahamnya ini menunjukkan prestasi entitasnya dan harga sahamnya bergerak dengan berbanding lurus dengan laba. Harga saham memiliki rata-rata berfluktuatif menyebabkan terjadinya kenaikan maupun penurunannya. Adapun beberapa faktor yang mempengaruhi harga saham Entitas barang konsumsi seperti profitabilitas, dividend payout ratio dan inflasi.

Pada PT. Mayora Indah, Tbk tahun 2015-2016, laba bersih setelah pajaknya mengalami peningkatan dari $\mathrm{Rp}$ 1.250.233.128.560 ke- Rp 1.388.676.127.665, tetapi harga sahamnya mengalami penurunan dari Rp $30.500 \mathrm{ke}-\mathrm{Rp}$

* Corresponding Author
1.645 per lembar saham, Hal ini tidak sesuai dengan teori Weston dan Brigham (2001), dimana jika laba bersih meningkat, maka harga saham juga harusnya meningkat. Dimana disini pemilik saham banyak mendapatkan keuntungan. Menurut Raden Neneng dan Aryati (2008) menjelaskan hal ini dikarenakan investor dalam memutuskan untuk menanamkan modalnya di suatu perusahaan, akan terlebih dahulu menilai prospek perusahaan tersebut yang ditunjukan dengan keuntungan yang positif akan berdampak pada return yang tentunya diharapkan menguntungkan bagi investor.

Pada PT.Wismilak Inti Makmur Tbk tahun 2016-2017, dividennya mengalami peningkatan dari Rp 28.348.295.760 ke- 52.496.844.000, tetapi harga sahamnya mengalami penurunan dariRp 440 ke- Rp 290 per lembar sahamnya, hal tersebut tidak sesuai dengan teori Weston dan Brigham (2001) yaitu jika dividen naik, maka harga saham juga seharusnya naik. Daya tarik akibat dividen yang didapatkan oleh pemegang saham yang semakin meningkat seharusnya harga saham juga semakin meningkat. Menurut Nor Hadi (2015) menyebutkan: Dividen merupakan keuntungan yang diberikan kepada para pemegang saham yang bersumber dari kemampuan emiten mencetak laba bersih dari 
operasinya sehingga laba biasanya menjadi dasar penentuan pembayaran dividen karena dividen merupakan bagian laba dari perusahaan yang dibagikan kepada pemegang saham dan juga dapat mempengaruhi kenaikan nilai saham di 47 masa mendatang.

Pada PT.Sekar Laut,Tbk, tahun 2015-2016 inflasi perusahaan mengalami penurunan dari 3,35 ke- 3,02 tetapi harga sahamnya juga mengalami penurunan dari $370 \mathrm{ke}-$ 308 per lembar saham, seperti yang dikemukakan Samsul, (2006) dimana seharusnya jika inflasi menurun, maka harga saham seharunya meningkat. Menurut Andriyani dan Armereo (2016) Inflasi yang tinggi menyebabkan menurunnya profitabilitas suatu perusahaan sehingga akan menurunkan pembagian dividend dan daya beli masyarakat juga menurun. Sehingga inflasi yang tinggi, mempunyai hubungan dengan pasar saham. Sedangkan menurut Tandelilin (2010), peningkatan inflasi secara relatif merupakan sinyal negatif bagi pemodal di pasar modal.

Tujuan penelitian ini adalah untuk mengetahui pengaruh profitabilitas terhadap harga saham, pengaruh dividend payout ratio terhadap harga saham, pengaruh inflasi terhadap harga saham, pengaruh profitabilitas, dividend payout ratio, dan inflasi terhadap harga saham.

Rumusan masalah penelitian ini adalah bahwa peningkatan profitabilitas tidak selalu diikuti dengan peningkatan harga saham, peningkatan dividend payout ratio tidak selalu diikuti dengan peningkatan harga saham, penurunan inflasi tidak selalu diikuti dengan peningkatan harga saham, peningkatan profitabilitas, dividend payout ratio dan penurunan inflasi tidak selalu diikuti dengan peningkatan harga saham

\section{Kajian Teori}

Profitability ratio menurut Fahmi (2012) merupakan rasio pengukur efektivitasnya keuntungan yang didapatkan Entitas besar maupun kecil yang berkaitan dengan penjualan maupun investasi yang dilakukannya. Kemampuan perusahaan dalam memperoleh laba dapat diukur melalui modal sendiri hingga dari seluruh dana yang diinvestasikan ke dalam perusahaan (Wiagustini, 2014).

$$
\text { ROA }=\underline{\text { Earning After Tax (EAT) }}
$$
Total Assets

Lebih lanjut, harga saham menurut Egam dan Pangerapan (2017:107) yakni harga yang ditetapkan atas tiap lembar saham yang diperjualbelikan. Menurut Kodrat dan Indonanjaya (2010:3-4), harga saham menggambarkan tiap lembar saham memiliki harga saat dilakukan perjualbelikan. Hartono (2016: p. 180) menyatakan nilai perusahaan ditunjukkan dengan harga saham dan sebagai pengukur efektivitas perusahaan

Harga saham = Harga Penutupan Saham (ditetapkan pada akhir tahun)

Fauza dan Mustanda (2017) Return on Asset yang tinggi menunjukkan daya mampu yang dimiliki Entitas dalam memperoleh laba tinggi mengakibatkan harga saham tinggi.

H1:Profitabilitas berpengaruh terhadap Harga Saham Pada Entitas Barang Konsumsi yang terdaftar di Bursa Efek Indonesia tahun 2014-2018.
Dividend payout ratio (DPR) menurut Murhadi (2013) ialah alat ukur proporsi besarnya dividend yang dibagikan atas laba didapatkan Entitas.

$$
\mathrm{DPR}=\frac{\underline{\text { Dividen }}}{\text { Net Income }}
$$

Bailia, Tommy dan Baramulli (2016) berpendapat, tingginya dividend yang dibayarkan menyebabkan harga sahamnya ikut naik. Lebih lanjut, bagi Nugraha dan Sudaryanto (2016), tingginya DPR selaras dengan peningkatan jumlah investor $\mathrm{p}$ e $\mathrm{m}$ b e 1 i saham tersebut, dan pada akhirnya berdampak pada peningkatan harga saham. $\mathrm{H}_{2}$ : Dividend Payout Ratio berpengaruh Terhadap Harga Saham Pada Entitas Barang Konsumsi yang terdaftar di Bursa Efek Indonesia Tahun 2014-2018.

Fahmi (2015) mendefinisikan inflasi sebagai kejadian yang mencerminkan keadaan terjadinya kenaikan harga barang dimana melemahnya mata uang rupiah. Inflasi dapat dilihat dari www.bi.go.id. Menurut Annisa (2015) tingginya inflasi mengakibatkan laba menurun dan harga saham ikut menurun.

H3 : Inflasi berpengaruh Terhadap Harga Saham Pada Entitas Barang Konsumsi yang terdaftar di Bursa Efek Indonesia Tahun 2014-2018.

\section{Metode}

Jenis penelitian ini adalah kuantitatif, dimana penelitian kuantitatif banyak menggunakan angka. Menurut Arikunto (2013) metode penelitian kuantitatif adalah: "Penelitian kuantitatif sesuai dengan namanya, banyak dituntut menggunakan angka, mulai dari pengumpulan data, penafsiran terhadap data tersebut, serta penampilan hasilnya."

\section{Desain Penelitian}

Penelitian ini mengarah kepada kriteria perusahaan yang terdaftar BEI, perusahaan yang melaporkan laporan keuangannya, dan perusahaan yang memiliki laba periode 2014-2018.

\section{Jenis dan Sumber Data}

Penelitian ini menggunakan data sekunder yang bersumber dari Bursa Efek Indonesia (www.idx.co.id). Menurut Sugiyono (2017) menjelaskan data sekunder adalah "Sumber data yang tidak langsung memberikan data kepada pengumpul data. Data sekunder ini merupakan data yang sifatnya mendukung keperluan data primer seperti bukubuku, literatur dan bacaan yang berkaitan dan menunjang penelitian ini".

\section{Populasi dan Sampel}

Populasi sebanyak 41 Entitas barang konsumsi yang terdaftar di BEI tahun 2014-2018. Sampel penelitian ini dipilih berdasarkan metode purposive sampling, yang berarti pengambilan sample didasarkan atas pertimbangan tertentu dari peneliti. Menurut Sugiyono (2012) menjelaskan bahwa purposive sampling adalah teknik penentuan sampel dengan pertingbangan tertentu. Sample penelitian ini harus memenuhi kriteria yang digunakan sebagai berikut: 1.Entitas barang konsumsi yang terdaftar di BEI Tahun 2014 hingga 2018, 2.Entitas barang konsumsi yang menerbitkan laporan keuangan tahun 2014 hingga 2018, 3.Entitas barang 
konsumsi yang menghasilkan laba selama tahun 2014 hingga 2018. Ada 17 perusahaan yang memenuhi ke-3 kriteria tersebut, kemudian dikali 5 tahun $=85$ sampel.

\section{Metode Analisis Data}

Penelitian ini menggunakan analisis regresi linier berganda, dimana penelitian ini menganalisis datanya dengan menguji perubahan pengaruh independennya terhadap dependen secara parsial maupun simultan. Menurut Sugiyono (2010) : "Analisis yang digunakan peneliti, bila bermaksud meramalkan bagaimana keadaan (naik turunnya) variabel dependen (kriterium), bila dua atau lebih variabel independen sebagai faktor prediktor dimanipulasi (dinaik turunkan nilainya)". Olah data menggunakan SPSS, adapun persamaan linier berganda sebagai berikut:

$$
\begin{array}{ll}
\mathrm{Y} & =\mathrm{a}+\mathrm{b} 1 \mathrm{X} 1+\mathrm{b} 2 \mathrm{X} 2+\mathrm{b} 3 \mathrm{X} 3+\mathrm{e} \\
\mathrm{Y} & =\text { Harga Saham } \\
\mathrm{a} & =\text { Konstanta } \\
\mathrm{b} & =\text { Koefisien masing variable } \\
\mathrm{X} 1 & =\text { Profitabilitas } \\
\mathrm{X} 2 & =\text { Dividend Payout Ratio } \\
\mathrm{X} 3 & =\text { Inflasi } \\
\mathrm{e} & =\text { Presentase Kesalahan }(5 \%)
\end{array}
$$

\section{Hasil dan Pembahasan}

\section{Hasil Deskripsi Statistik}

Berdasar pada Tabel.1 deskripsi statistik diatas: (1) Profitabilitas berjumlah 85 , min 0,03, max 0,53, mean

\begin{tabular}{|c|c|c|c|}
\hline \multicolumn{4}{|c|}{ Descriptive Statistics } \\
\hline & Mean & Std. Deviation & $\mathrm{N}$ \\
\hline Harga_Saham & 14848,9647 & 26517,84336 & 85 \\
\hline \multirow[t]{2}{*}{ Profitabilitas } & 236780180105 & 333277612354 & 85 \\
\hline & 6,4590 & 9,15040 & \\
\hline DPR &, 8546849 & 3,64100024 & 85 \\
\hline Inflasi & 4,2940 & 2,05513 & 85 \\
\hline
\end{tabular}
0,1461 dan std.deviasi $0,11733,(2)$.Dividend payout ratio berjumlah 85 , min 0,00 , max 33,86, mean 0,8545 dan std deviasi 3,64112, (3) Inflasi berjumlah 85, min 3,02, max 8,36, mean 4,2940 dan std deviasi 2,05513, (4) Harga saham berjumlah 85, min 284,00, max 160000, mean 14848,9647 dan std.deviasi 26517,84336.

Tabel 1. Deskripsi Statistik

Sumber: olah data dengan SPSS, 2020

Model Analisis Linear Berganda

Tabel 2. Hasil Analisis Linier Berganda

\begin{tabular}{lcccrrr}
\hline & \multicolumn{2}{c}{$\begin{array}{c}\text { Unstandardized } \\
\text { Coefficients }\end{array}$ Model } & \multicolumn{2}{c}{$\begin{array}{c}\text { Stand. } \\
\text { Coeff. }\end{array}$} & \multirow{2}{*}{ S } & Sig. \\
\cline { 2 - 4 } & B & $\begin{array}{c}\text { Std. } \\
\text { Error }\end{array}$ & Beta & & \\
\hline (Constant) & 10.13 & 0.802 & & 12.63 & 0 \\
LN_X1 & 0.888 & 0.238 & 0.391 & 3.726 & 0 \\
LN_X2 & 0.351 & 0.207 & 0.179 & 1.699 & 0.093 \\
LN_X3 & 0.346 & 0.427 & 0.082 & 0.809 & 0.421 \\
\hline
\end{tabular}

a. Dependent Variable: LN_Y

Sumber: olah data dengan SPSS, 2020

$$
\mathrm{Y}=10.130+0,888 \mathrm{X} 1+0,351 \mathrm{X} 2+0,346 \mathrm{X} 3+\mathrm{e}
$$

\section{Uji Statistik F}

Tabel 3. Hasil Uji Statistik F

\begin{tabular}{rlrrrrr}
\hline \multicolumn{7}{c}{ ANOVA $^{\mathrm{a}}$} \\
\hline \multirow{2}{*}{ Model } & $\begin{array}{l}\text { Sum of } \\
\text { Squares }\end{array}$ & df & $\begin{array}{c}\text { Mean } \\
\text { Square }\end{array}$ & F & Sig. \\
\hline \multirow{2}{*}{1} & Regression & 47.255 & 3 & 15.752 & 7.5 & $.000^{\mathrm{b}}$ \\
& $\begin{array}{l}\text { Residual } \\
\text { Total }\end{array}$ & 158.977 & 76 & 2.092 & & \\
\hline
\end{tabular}

a. Dependent Variable: LN_Y

b. Predictors: (Constant), LN_X3, LN_X1, LN_X2

Sumber: olah data dengan SPSS, 2020

F-hitung $=7,530, \operatorname{sig}=0,000$ dan Ftabel $(80-4=76)=2,72$. Fhitung > F-tabel $(7,530>2,72)$ maka Ho ditolak dan $\mathrm{Ha}$ diterima, artinya profitabilitas, dividend payout ratio, dan inflasi secara simultan berdampak dan signifikan terhadap Harga Saham Entitas Barang Konsumsi yang listed pada BEI dari tahu 2014-2018.

\section{Uji Statistik T}

Tabel 4. Hasil Uji Statistik T

\begin{tabular}{lcccrr}
\hline \multirow{2}{*}{ Model } & \multicolumn{2}{c}{$\begin{array}{c}\text { Unstandardized } \\
\text { Coefficients }\end{array}$} & $\begin{array}{l}\text { Stand. } \\
\text { Coeff. }\end{array}$ & \multirow{2}{*}{ t } & Sig. \\
\cline { 2 - 4 } & B & $\begin{array}{c}\text { Std. } \\
\text { Error }\end{array}$ & Beta & & \\
\hline (Constant) & 10.13 & 0.802 & & 12.6 & 0 \\
LN_X1 & 0.888 & 0.238 & 0.391 & 3.73 & 0 \\
LN_X2 & 0.351 & 0.207 & 0.179 & 1.7 & 0.093 \\
LN_X3 & 0.346 & 0.427 & 0.082 & 0.81 & 0.421 \\
\hline
\end{tabular}

a. Dependent Variable: LN_Y

Sumber: olah data dengan SPSS, 2020

1. Profitability t-hitung $=3,726$, sig $=0,000$ dan t-tabel (80$3=77)$ adalah 1,991, maka t-hitung > t-tabel (3,726>1,991), sehingga $\mathrm{Ho}$ di tolak dan $\mathrm{Ha}$ diterima, artinya Profitabilitas berpengaruh secara signifikan terhadap Harga Saham Entitas Barang Konsumsi listed di BEI dari 2014 hingga 2018.

2. Dividend payout ratio (DPR) t-hitung $=1,699$, $\mathrm{sig}=$ 0,093 dan t-tabel $(80-3=77)$ adalah 1,991 , maka thitung<t- tabel $(1,699<1,991)$ sehingga Ho diterima dan $\mathrm{H}_{\mathrm{a}}$ ditolak artinya DPR tidak berpengaruh terhadap Harga Saham Entitas Barang Konsumsi listed di BEI dari 2014 hingga 2018.

3. Inflasi thitung $=0,809$, sig $=0,42$ dan t-tabel $(80-3=77)$ adalah 1,991, maka t-hitung < t-tabel $(0,809<1,991)$ sehingga Ho diterima dan $\mathrm{Ha}_{\mathrm{a}}$ ditolak, artinya dampak Inflasi tidak berpengaruh terhadap Harga Saham Entitas Barang Konsumsi listed di BEI dari 2014 hingga 2018.

\section{Pembahasan}

\section{Pengaruh Profitabilitas pada Harga Saham}

Kajian ini menyimpulkan Profitabilitas berpengaruh pada Harga Saham Entitas Barang Konsumsi listed di BEI dari 2014 hingga 2018. Kajian ini mendukung kajian dari Fauza dan Mustanda (2017) Semakin meningkatnya profitabilitas 
Entitas justru meningkatkan harga saham sehingga investor akan menerima kenaikan pula atas saham yang diinvestasikannya.

Menurut Manullang, dkk (2019) Ketika mengevaluasi perusahaan, adalah tidak cukup hanya mengetahui bagaimana laba bersih meningkat atau menurun,investor biasanya akan lebih fokus dengan melihat bagaimana perubahan laba bersih yang dihasilkan investee telah mempengaruhi investasinya dan harga saham.

\section{Pengaruh Dividend Payout Ratio (DPR) Terhadap HargaSaham}

Kajian ini menyimpulkan bahwa tak adanya dampak $D P R$ pada Harga Saham Entitas Barang Konsumsi listed di BEI dari 2014 hingga 2018, sehingga sependapat dengan kajian Nugraha dan Sudaryanto (2016). Nugraha dan Sudaryanto (2016) menemukan bahwa pembayaran dividen lebih dipilih pemegang saham daripada capital gain, oleh karenanya investor cenderung tertarik pada korporasi dengan rasio DPR yang lebih besar. Itu berarti makin banyaknya investor yang menanamkan saham, making tinggi pula harga sahamnya.

\section{Pengaruh Inflasi Terhadap Harga Saham}

Kajian ini menyimpulkan bahwa tak adanya dampak inflasi pada Harga Saham Pada Entitas Barang Konsumsi listed di BEI dari 2014 hingga 2018, kajian ini sejalan denganPenelitian yang dilakukan oleh Napitupulu (2012), Nuriawan (2015), dan Ginting et al. (2016) dan Utommo (2016) menyatakan bahwa variabel inflasi tidak memiliki pengaruh yang signifikan terhadap harga saham. Tetapi tidak sejalan dengan penelitian Windasari (2015) maupun Ulandari (2017) dimana hasil penelitian mereka menyatakan bahwa inflasi berpengaruh signifikan terhadapharga saham.

\section{Simpulan dan Implikasi Penelitian}

Profitabilitas berpengaruh dengan signifikan terhadap harga saham pada entitas barang konsumsi yang terdaftar di bursa efek indonesia tahun 2014-2018, artinya pada secara umum laba bersih setelah pajak mempengaruhi harga saham yang beredar pada perusahan barang komsumsi. Kenaikan laba bersih yang tidak diikuti dengan kenaikan harga saham pada saat itu adalah dikarenakan laba bersih setelah pajak pada saat itu dipergunakan untuk kebutuhan perusahaan atau tidak dibagikan secara dividen ke pemegang saham, sehingga calon investor cenderung untuk tidak membeli saham pada perusahaan barang dan komsumsi ini, sehingga harga sahamnya menjadi turun.

Dividend payout ratio tidak berpengaruh terhadap harga saham pada entitas barang konsumsi yang terdaftar di bursa efek indonesia tahun 2014-2018, artinya walaupun dividen naik, tetapi tidak mempengaruhi investor pada saat dengan saham perusahaan barang konsumsi, sehingga harga sahamnya menjadi turun.

Inflasi tidak berpengaruh terhadap harga saham pada entitas barang konsumsi yang terdaftar di bursa efek indonesia tahun 2014-2018, artinya inflasi pada saat itu tidak ada pengaruhnya terhadap penurunan harga saham pada perusahaan barang komsumsi.
Profitabilitas, dividend payout ratio dan inflasi secara simultan berpengaruh dan signifikan terhadap harga saham pada entitas barang konsumsi yang terdaftar di bursa efek indonesia tahun 2014-2018, artinya Profitabilitas, dividend payout ratio dan inflasi jika terjadi secara bersamaan maka akan mempengaruhi harga saham pada perusahaan barangkomsumsi.

Penelitian ini sangat terbatas, karena Vareabel indevenden yang digunakan hanya tiga, Profitabilitas, dividend payout ratio dan inflasi Kurangnya waktu menjadikan perolehan data menjadi kurang efektif dan konsisten dalam melihat pengaruh Profitabilitas, dividend payout ratio dan inflasi terhadap harga saham.

Rekomendasi kepada investor adalah jika hendak melakukan investasi di perusahaan barang komsumsi, sebaiknya perhatikan laba bersih setelah pajaknya. Secara bersamaan perhatikan profitabilitas, dividend payout ratio, dan inflasinya apakah baik atau buruk, barulah memutuskan untuk melakukan investasi.

\section{Ucapan Terima Kasih}

Terima kasih kepada para dosen UNPRI dan teman teman mahasiswa yang telah memberikan arahan dan membantu penulis, sehingga penelitian ini biasa menjadi lebih sempurna.

Terima kasih kepada BEI yang telah membantu penulis memberikan data perusahaan barang komsumsi yang terdaftar di Bursa Efek Indonesia.

\section{Referensi}

Annisa,N. 2015. Pengaruh Profitabilitas, Umur, dan Ukuran Perusahaan Terhadap Corporate Social Responbility. e-Proceeding of Management. Vol2, No.1, hlm 313. ISSN : 2355-9357

Andriyani,I., dan A.Crystha. 2016. Pengaruh Inflasi Dan Tingkat Bunga Terhadap Indeks Harga Saham Gabungan (Ihsg) Pada Bursa Efek Indonesia. Jurnal Manajemen dan Bisnis Sriwijaya Vol. 14 No.1 hal 43-60, Palembang.

Arikunto, S. 2013. Prosedur Penelitian: Suatu Pendekatan Praktik. Jakarta: Rineka Cipta.

Egam,I., dan Pangerapan. 2017. Pengaruh ROA, ROE, NPM dan EPS terhadap Harga Saham Perusahan yang tergabung dalam Indeks LQ45 di BEI Periode 2013-2015. Jurnal EMBA. Vol 5 No 1 Tahun 2017. Universitas Sam Ratulangi Manado.

Fauza,M.S., dan I K. Mustanda 2017. pengaruh profitabilitas, earning per share (eps) dan dividend payout ratio (dpr) terhadap harga saham. E- Jurnal Manajemen, Vol 5 No.12

Fahmi,I. 2012. Pengantar Manajemen Keuangan. Bandung: Penerbit Alfabeta.

Ginting. M. R .M, Topowijonodan Sri Sulasmiyati. 2016. Pengaruh Tingkat Suku Bunga, Nilai Tukardan Inflasi terhadap Harga Saham. Jurnal Akuntansi.Vol. 35. No. 2. Universitas BrawijayaMalang.

Hadi,N.2015. Pasar Modal (Edisi 2). Yogyakarat: Graha Ilmu.

Hartono, J. 2016. Teori Portofolio dan Analisis Investasi (10th ed.). Yogyakarta: BPFE. 
Kodrat,S., dan Indonanjaya. 2010. Manajemen Investasi. Ed. 1, Yogkakarta:Graha Ilmu.

Manullang, J., H.Sainan., Phillip., dan W. Halim. 2019. Pengaruh Rasio Profitabilitas, Solvabilitas,dan Likuiditas terhadap Harga Saham Pada Perusahaan Sektor Pertambangan yang Terdaftar di BEI Periode 2014-2018. RISET \& JURNAL AKUNTANSI, Volume 3 Nomor 2. Medan.

Murhadi,W. 2013. Analisis Laporan Keuangan Proyeksi dan Valuasi Saham. Jakarta : Penerbit Salemba Empat.

Napitupulu, Lasma Riana. 2012. Analisis Hubungan Inflasi, Nilai Tukar, Tingkat Bunga terhadapIndeks Harga Saham Gabungan di Bursa Efek Indonesia. Skripsi. Universitas Indonesia,Jakarta.

Nugraha,D.S. 2016. Analisis Pengaruh DPR, DER, ROE dan TATO terhadap Harga Saham (Studi Kasus oada Perusahaan Industri Dasar dan Kimia yang terdaftar di BEI Periode 2010-2014). Diponegoro Journal of Management. Vol 5 No 4 Tahun 2016. Universitar Diponegoro.

Nugraha,R.D.,dan B.Sudaryanto. 2016. Analisis Pengaruh DPR, DER, ROE, dan TATO Terhadap Harga Saham pada Perusahaan Industri Dasar dan Kimia yang Terdaftar di BEI Periode 2010- 2014. Diponegoro Journal. ISSN 2337-3792 5(4):112.

Nuriawan, Agustinus Endi. 2015. Analisis Pengaruh Inflasi, Suku Bungadan Nilai Tukar Rupiah terhadap Indeks Harga Saham Gabungan(IHSG) di Bursa Efek Indonesia. Skripsi. Universitas Sanata Dharma, Yogyakarta.

Raden, N.R., dan Aryati. 2008. Pengaruh Earning Per Share terhadap Harga Saham. Jurnal Akuntansi FE Unsil, Vol. 3, No. 2.

Samsul, Mohamad. 2006. Pasar Modal dan Manajemen Portofolio. Jakarta: Erlangga

Sanusi, A. 2013. Metodologi Penelitian Bisnis. Jakarta : Penerbit Salemba Empat.

Sugiyono. 2010. Metode Penelitian Pendidikan Pendekatan Kuantitatif, kualitatif, dan $R \& D$. Bandung: Alfabeta.

Sugiyono. 2012. Metode Penelitian Manajemen. Jakarta : Penerbit CV Alfabeta.

Sugiyono. 2017. Metode Penelitian Kuantitatif, Kualitatif, dan $R \& D$. Bandung: Alfabeta, CV.

Tandelilin, Eduardus. 2010. Analisis Investasi dan Manajemen Portofolio. Edisi Ketujuh. Kanisius. Yogyakarta

Ulandari, Susi. 2017. Pengaruh Inflasi dan Nilai Tukar Rupiah terhadap Harga Saham di Sektor Industri Barang Konsumsi pada Indeks Saham Syariah Indonesia (ISSI) Tahun 2012-2016. Skripsi. UIN Raden Fatah,Palembang.

Wiagustini, N. L. P. 2014. Manajemen Keuangan (1st ed.). Denpasar: Udayana University Press.

Windasari, Alfa Nur. 2015. Analisis Pegaruh Tingkat Inflasi, Nilai Kurs Rupiah, Tingkat Suku Bunga terhadap Harga Saham di Bursa Efek Indonesia. Skripsi. Universitas Muhammadiyah Surakarta, Surakarta. 